\title{
IMPORTANCE OF ROENTGEN TUBE ANGLES IN CINEFLUOROSCOPIC INVESTIGATION OF MECHANICAL PROSTHESES
}

Uğur Coşkun, Barış Ökçün, Murat Başkurt, Kadriye Kılıçkesmez, Cem Bostan, Ahmet Yıldız, Alev Arat, Tevfik Gürmen, Mehmet Serdar Küçükoğlu

\begin{abstract}
Aim. We planned a cinefluoroscopy (CF) study to mark the ideal opening and closing tube angles for mitral and aortic positioned mechanical valves. Our hypothesis was that if we find an intensity zone where the valves were optimally seen, then starting the CF examination from that tube position would shorten the examination duration

Material and methods. Between January 2010 and August 2011, 192 consecutive patients (mean age $51,86 \pm 12,80$ years; 101 women and 91 male) with mitral ( $n=135$; monoleaflet: 37 ; bileaflet: 98$)$ and aortic ( $n=87$; monoleaflet:19; bileaflet: 68$)$ and tricuspid ( $n=3$; all bileaflet) prostheses were enrolled into the study. Cinefluoroscopy was performed with Philips Radiologic System. For each type and location of mechanical prostheses optimal opening-closing angles obtained and marked on $\mathrm{x}-\mathrm{y}$ axis graphic. Furthermore, we investigated whether there is an intensity zone quadrant. Results. Among patients with prosthetic bileaflet mitral valve in supine position optimal images were obtained: 34 (58,6\%) patients were in RAO-Cranial, $12(20,7 \%)$ were in left anterior oblique (LAO) cranial, 7 (12,1\%) were in RAO caudal and 5 (8,6\%) were in LAO caudal angles. Among patients with prosthetic bileaflet aortic valves in supine position shown: 27 (50\%) patients were in LAO-cranial, 10 (18,5\%) were in RAO- cranial, 9 $(16,7 \%)$ were in LAO-caudal and $8(14,8 \%)$ patients were in RAO-caudal angles. Conclusion. According to our results it seems logical to start mitral position CF assessment by RAO-Cranial angles quadrant and for aortic position by LAO-Cranial angles quadrant to decrease time and lower radiation exposure.
\end{abstract}

\author{
Russ J Cardiol 2014, 1 (105), Engl.: 23-26
}

Key words: cinefluoroscopy, mechanical heart valve dysfunction, radiation consumption.

Department of Cardiology, Istanbul University Institute of Cardiology, Istanbul, Turkey.

Corresponding author. Uğur Coşkun, MD, Istanbul University Institute of Cardiology, Department of Cardiology, Cardiologist, Instructor, Haseki Street, Haseki, Aksaray/Fatih 34350, Istanbul/Turkey, Tel: +902124592000 , Fax: +902124592069, e-mail: drugurcoskun@gmail.com

CF - Cinefluoroscopy, LAO - Left anterior oblique, RAO - Right anterior oblique, SPSS - Statistical Package for Social Sciences, TEE - Transesophageal echocardiography, TTE - Transthoracic echocardiography.

Received June 29, 2013.

Revision received July 04, 2013.

Accepted July 11, 2013.

\section{ВАЖНОСТЬ УГЛОВ РЕНТГЕНОВСКОЙ ТРУБКИ В КИНОФЛЮОРОГРАФИЧЕСКОМ ИССЛЕДОВАНИИ МЕХАНИЧЕСКИХ ПРОТЕЗОВ}

Uğur Coşkun, Barış Ökçün, Murat Başkurt, Kadriye Kılıçkesmez, Cem Bostan, Ahmet Yıldız, Alev Arat, Tevfik Gürmen, Mehmet Serdar Küçükoğlu

Цель. Мы планировали кинофлюорографическое исследование (КФ), чтобы отметить идеальное открытие и закрытие углов трубки для митрального и аортального механических клапанов. Наша гипотеза, что если мы найдем зону интенсивности, где клапаны были бы оптимально видны, то, начало КФ с этого положения трубки позволило бы сократить продолжительность исследования.

Материал и методы. В период с января 2010 года по август 2011 г. 192 паци-

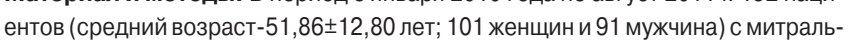
ным (n=135; одностворчатый: 37; двухстворчатый: 98), аортальным (n=87; одностворчатый:19; двухстворчатый: 68$)$ и трикуспидальным ( $n=3$; все двухстворчатый) протезами были включены в исследование. КФ была выполнена с помощью Philips Radiologic System. Для каждого типа и местоположения механических протезов оптимальные углы открытия-закрытия были получены и отмечены на х-у оси графика. Кроме того, мы исследовали, имеется ли квадрант интенсивности зоны.

Результаты. Среди больных с протезированным двухстворчатым митральным клапаном в положении лежа на спине были получены оптимальные изо-

\section{Introduction}

Prosthetic cardiac valves have been used commonly for four decades. Although mechanical cardiac valve related complications are rare; thrombus formation and pannus ingrowths are serious and fatal problems leading to valve obstruction [1-3]. Transthoracic (TTE) and transesophageal echocardiography (TEE) are the standard techniques for the evaluation of prosthetic valve function [4-8]. Quantitative evaluation of leaflet (s) motion is very important. бражения: 34 (58,6\%) больных были в правом переднем косом положении (RAO) краниальной проекции, 12 (20,7\%) были в левом переднем косом положении (LAO) краниальной проекции, 7 (12,1\%) были в RAO каудальной проекции и 5 (8,6\%) были в LAO каудальной проекции. Среди больных с протезированным двухстворчатым аортальным клапаном в положении лежа на спине показано: 27 (50\%) больных были в LAO краниальной проекции, 10 (18,5\%) были в RAO краниальной проекции, 9 (16,7\%) были в LAO каудальной проекции и $8(14,8 \%)$ больных были в RAO каудальной проекции углов.

Заключение. Согласно нашим результатам, кажется логичным начинать оценку митральной позиции КФ с определения квадранта углов RAO краниальной проекции и аортальной - c LAO краниальной проекции, что позволит сократить время и снизить облучение.

Российский кардиологический журнал 2014, 1 (105), Англ.: 23-26

Ключевые слова: кинофлюорографическое исследование, механические клапаны сердца, дисфункция, излучение.

Leaflet (s) opening and closing angle measurements provide important information to recognize prosthetic dysfunction. For this purpose, cinefluoroscopy (CF) is considered the "gold standard" technique $[9,10]$. Although CF investigation is practical and beneficial, sometimes it requires long examination durations causing prolonged radiation exposure both for the patient and the cardiologist.

During CF investigation of a particular mechanical heart valve optimal view of mechanical valve's opening 
and closing functions are not known. If this was known the radiation duration could be shortened. We could not find any study dealing with this problem. Therefore, we planned a CF study to mark the ideal opening and closing tube angles for mitral and aortic positioned mechanical valves. Our hypothesis was that if we find an intensity zone where the valves were optimally seen, then starting the CF examination from that tube position would shorten the examination duration.

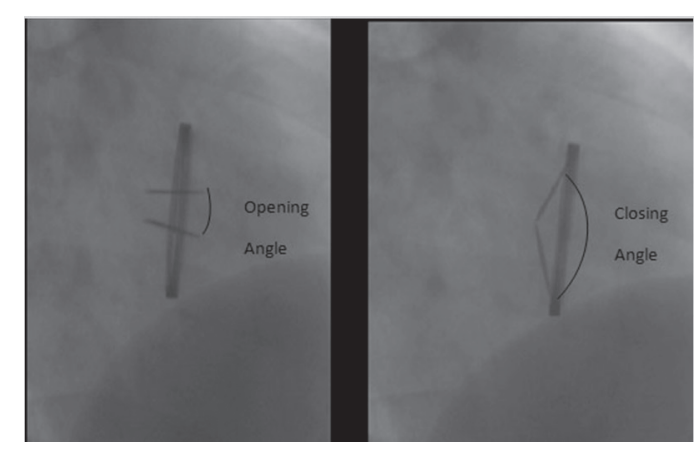

Figure 1. Optimal cinefluoroscopic opening and closing.

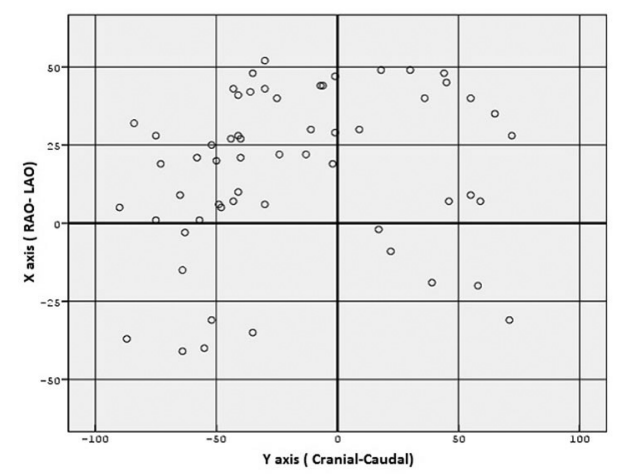

Figure 2. Patients with prosthetic bileaflet mitral valve in supine position. Abbreviations: LAO - Left anterior oblique position tube angles, RAO - Right anterior oblique position.

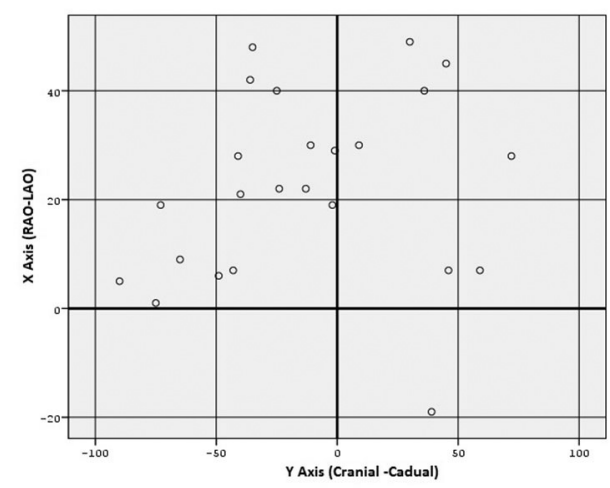

Figure 3. Patients with prosthetic monoleaflet mitral valve in supine position. Abbreviations: LAO - Left anterior oblique position tube angles, RAO - Right anterior oblique position.

\section{Material and methods}

Between January 2010 and August 2011, 192 consecutive patients (mean age $51,86 \pm 12,80$ years; 101 women and 91 male) with mitral ( $n=135$; monoleaflet:37; bileaflet:98), aortic ( $n=87$; monoleaflet:19; bileaflet:68) and tricuspid ( $n=3$; all bileaflet) prostheses were enrolled into the study. The local ethics committee approved the study protocol, and written informed consent was obtained from all the patients. Patients with normal functioning mechanical valves were selected from our echocardiography laboratory. CF was performed with Philips Radiologic System on the day of the TTE examination. Every prosthetic valve was viewed in multiple projections including cranio-caudal angulations. The evaluation was considered appropriate when the prosthetic valve ring and tilting disk projection parallel to $\mathrm{x}$-ray beam was obtained. In optimal cine-fluoroscopic image the valve leaflet (s) should display thin and linear appearance. This view allows the proper visualization of prosthetic leaflet motion so that opening and closing angles can be calculated (Fig. 1). To achieve optimal CF image, we started the examination first from the supine position and continued respectively with right lateral decubitus, left lateral decubitus, prone positions, and the modified versions of these positions (in lateral decubitus positions; semi-elevation of upper body, in prone position; semi-elevation of upper body, like the baby birth position, in supine position; semi-elevation of upper body and prostrate in prayer position are the examples of modified positions), in order to search for the optimal image. When optimal image was achieved $\mathrm{x}$-ray tube angles were written down and 3 to 10 cardiac cine- cycles were recorded. Optimal $\mathrm{CF}$ angle was marked on $\mathrm{x}-\mathrm{y}$ axis graphic for each valve separately. Patient's radiation doses were below the diagnostic coronary angiography.

Statistical analysis. Statistical analysis was performed using SPSS (Statistical Package for Social Sciences) for Windows version 12 (Chicago, Illinois, USA). Continuous variables were expressed as mean $\pm \mathrm{SD}$, while categorical variables were displayed in numbers and percentages. Scatter dot graphics were used to determine the X-ray tube angles.

\section{Results}

Between January 2010 to August 2011, 192 patients with prosthetic cardiac valves were evaluated by fluoroscopy. $91(47,3 \%)$ were male and $101(52,6 \%)$ were female. $101(44,4 \%)$ patients had prosthetic mitral valve, 58 $(25,5 \%)$ had prosthetic valve in the aortic position, Thirty three patients had double prosthetic valves. Thirty $(13,2 \%)$ patients had prosthetic valves both in mitral and aortic positions, and $3(1,6 \%)$ patients had prosthetic valves both in mitral and tricuspid positions. $56(24,7 \%)$ patients had monoleaflet prosthetic cardiac valves and $171(75,3 \%)$ had bileaflet valves. Baseline characteristics of study population are presented in Table 1. 
Fluoroscopic evaluation was performed respectively from supine, right lateral decubitus, left lateral decubitus and prone positions. Among patients with prosthetic bileaflet mitral valve, ideal $\mathrm{x}$-ray tube angles were found from supine position in $58(65,9 \%)$ patients, right lateral decubitus in $17(19,3 \%)$, left lateral decubitus in $8(9,1 \%)$, and in prone position in $5(5,7 \%)$ patients. As shown in Table 2 and Figure 2, most of the patients in supine position were shown in right anterior oblique (RAO) -cranial angles: 34 $(58,6 \%)$ patients were in RAO-Cranial angles, $12(20,7 \%)$ were in left anterior oblique (LAO) cranial angles. Total of $7(12,1 \%)$ patients were shown in RAO caudal angles and $5(8,6 \%)$ were in LAO caudal angles. Monoleaflet prosthetic mitral valves were mostly shown from supine position RAO-Cranial: $18(54,5 \%), 12(36,4 \%)$ were shown from LAO - cranial and only $3(9,1 \%)$ cases were shown from LAO caudal angles (Fig. 3).

Prosthetic aortic valves were also best shown from supine position in most of the cases. Of 68 patients with bileaflet prosthetic aortic valves, $54(79,4 \%)$ were shown from supine position, $9(13,2 \%)$ patients from right lateral decubitus position and $5(7,4 \%)$ patients from prone position. In supine position $27(50 \%)$ patients were shown from LAO-cranial, $10(18,5 \%)$ patients were in RAO cranial, $9(16,7 \%)$ patients were in LAO caudal angles and 8 $(14,8 \%)$ patients were in RAO caudal angles (Tab. 3, Fig. 4). From 19 monoleaflet prosthetic aortic valve; $14(73,7 \%)$ were shown from supine position, $3(15,8 \%)$ from prone position and $2(10,5 \%)$ patients from right lateral decubitus position.

\section{Discussion}

Although echocardiography is currently used routinely for the assessment of heart valve prostheses function, it has certain limitations that may be complemented with information provided by CF [11]. TTE, is usually unable to identify the type of heart valve prosthesis implanted, and frequently cannot detect opening and closing angles of the prosthetic leaflets because of metallic reverberations [11]. Therefore, CF assessment of mechanical heart valve prostheses is a complementary method to echocardiography [11]. CF, especially, should always be a part of diagnostic work-up if there is suspicion of prosthetic heart valve thrombosis and/or pannus formation causing mechanical valve dysfunction $[3,5,9,10]$.

However, achieving ideal opening and closing angles in some of the patients is very difficult and the CF examination may take longer and the radiation exposure may be excessive for both the patient and the physician. Gianculli et al. reported failure in obtaining ideal CF image in $26,7 \%$ of the prosthesis for mitral position and $6,9 \%$ for aortic position [11]. In our study, we did obtain optimal images, showing opening and closing angles in all of our patients. During CF, we started the examination first from the supine position and continued respectively with right lateral decubitus, left lateral decubitus, prone positions, and the modified versions
Table 1

\section{Baseline characteristics of study population}

\begin{tabular}{|l|l|}
\hline Age & $51,86 \pm 12,80$ \\
\hline Sex (Female\%) & $52,6 \%(101)$ \\
\hline Prosthetic aortic valve monoleaflet & $8,4 \%(19)$ \\
\hline Prosthetic aortic valve bileaflet & $30,2 \%(68)$ \\
\hline Prosthetic mitral valve monoleaflet & $16,4 \%(37)$ \\
\hline Prosthetic mitral valve bileaflet & $43,5 \%(98)$ \\
\hline Prosthetic tricuspid valve bileaflet & $1,3 \%(3)$ \\
\hline
\end{tabular}

Table 2

Patients with prosthetic bileaflet mitral valve in supine position

\begin{tabular}{|l|l|}
\hline RAO-Cranial Angles & $34(58,6 \%)$ \\
\hline LAO-Cranial Angles & $12(20,7 \%)$ \\
\hline RAO-Caudal Angles & $7(12,1 \%)$ \\
\hline LAO Caudal Angles & $5(8,6 \%)$ \\
\hline
\end{tabular}

Abbreviations: LAO - Left anterior oblique position tube angles, RAO - Right anterior oblique position.

Table 3

\section{Patients with prosthetic bileaflet aortic valve} in supine position

\begin{tabular}{|l|l|}
\hline RAO-Cranial Angles & $10(18,5 \%)$ \\
\hline LAO-Cranial Angles & $27(50 \%)$ \\
\hline RAO-Caudal Angles & $(14,8 \%)$ \\
\hline LAO Caudal Angles & $9(16,7 \%)$ \\
\hline
\end{tabular}

Abbreviations: LAO - Left anterior oblique position tube angles, RAO - Right anterior oblique position.

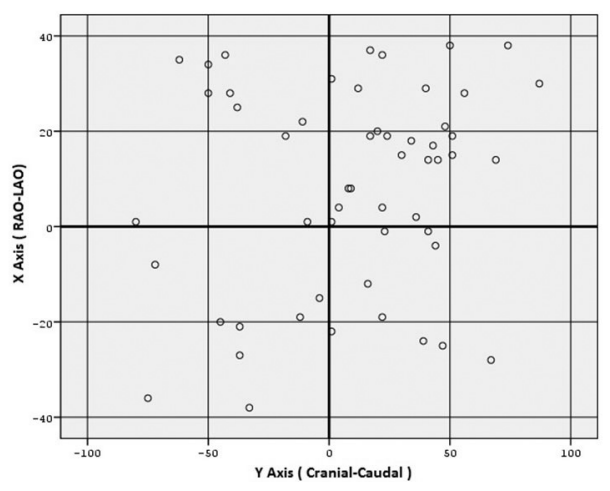

Figure 4. Patients with prosthetic bileaflet aortic valve in supine position. Abbreviations: LAO - Left anterior oblique position tube angles, RAO - Right anterior oblique position.

of these positions (in lateral decubitus positions; semi-elevation of upper body, in prone position; semi-elevation of upper body, like the baby birth position, in supine position; semi-elevation of upper body and prostrate in prayer position are the examples of modified positions), in order to search for the optimal image. These multiple positions and 
the modifications may explain our full achievement of the optimal image, unlike Gianculli et al.

Furthermore, we searched the literature to find a study investigating roentgen tube angle scatter chart in cranio-caudal and right-left oblique axis for mitral and aortic position mechanical prostheses, but we couldn't found any. Therefore, we planned this CF study to mark the ideal opening and closing tube angles for mitral and aortic position mechanical prosthesis to the right-left anterior oblique ( $\mathrm{X}$ axis) and cranio-caudal ( $\mathrm{Y}$ axis) planes. In the $\mathrm{X}-\mathrm{Y}$ axis graphic, we divided the graphic to four quadrants: RAO-Cranial, RAO-Caudal, LAO-Cranial and LAO-Caudal quadrants. Our hypothesis was if we find an intensity zone quadrant with our marked points in X-Y axis plane graphic which will be give us a logical starting point to $\mathrm{CF}$ investigation we would achieve less $\mathrm{CF}$ time and radiation exposure.

Our study showed that for mechanical prosthesis on mitral position optimal images were mostly at supine position [58 prostheses $(65,9 \%)]$ and RAO-Cranial angles quadrant [31 prostheses $(53,4 \%)]$. Left and right lateral decubitus and, prone patient positions did not have enough number to achieve intensity zone in X-Y axis graphic. In aortic mechanical prostheses optimal CF images were obtained mostly in supine patient position [54 patients $(79,4 \%)]$, and the intensity zone was found mostly (25 patients (46\%)) in LAO-Cranial angles quadrant.

\section{Conclusion}

Our results show that it is logical to start CF assessment of mechanical prosthesis by supine RAO-Cranial

\section{References}

1. Rizzoli G, Guglielmi C, Toscano G, et al. Reoperations for acute prosthetic thrombosis and pannus: an assessment of rates, relationship and risk. Eur $\mathrm{J}$ Cardiothorac Surg 1999;16:74-80.

2. Teshima $\mathrm{H}$, Hayashida $\mathrm{N}$, Yano $\mathrm{H}$, et al. Obstruction of St. Jude Medical valves in the aortic position: histology and immunohistochemistry of pannus. J Thorac Cardiovasc Surg 2003;126:401-7.

3. Aoyagi S, Nishimi Y, Kawano H, et al. Obstruction of St. Jude Medical valves in the aortic position: significance of a combination of cineradiography and echocardiography. $\mathrm{J}$ Thorac Cardiovasc Surg 2000;120:142-7.

4. Barbetseas J, Nagueh SF, Pitsavos C, et al. Differentiating thrombus from pannus formation in obstructed mechanical prosthetic valves: an evaluation of clinical, transthoracic and transesophageal echocardiographic parameters. J Am Coll Cardiol 1998;32:1410-7.

5. Montorsi P, De Bernardi F, Muratori M, et al. Role of cine-fluoroscopy, trans-thoracic and trans-esophageal echocardiography in patients with suspected prosthetic heart valve thrombosis. Am J Cardiol 2000;85:58-64.

6. Aoyagi S, Arinaga K, Fukunaga S, et al. Leaflet movement of the ATS valve in the aortic position: unique behaviour observed in 19-mm valves. Ann Thorac Surg 2006;82:853-7. angles quadrant in mitral position and by supine LAO-Cranial angles quadrant in aortic position to obtain less time consumption and lower radiation exposure. If we can't record ideal image in supine position as we described before we should search in left lateral decubitus and right lateral decubitus positions. If all these positions fail to record ideal leaflet opening and closing angles we can try prone position on roentgen table as a final resort. We recommend an initial CF examination after mechanical valve replacement and save the images to compare with a future CF examination if needed. These recordings will decrease time and radiation consumption in a future $\mathrm{CF}$ examination. Furthermore, if the patient has problem in lying down on roentgen table we can set the initial roentgen tube angles from our first $\mathrm{CF}$ recordings and take ideal image in very brief time.

Our study may hopefully give way to further largescaled studies, investigating $\mathrm{CF}$ examination specific to the location and type of the mechanical valve, in order to obtain an optimal imaging with shorter radiation exposure durations both for the patient and the physician.

\section{Study Limitations}

Most of our patients had bileaflet mechanical valves. Number of patients with monoleaflet valves was not enough to achieve an intensity zone on the RAO-LAO and cranial-caudal quadrants of the CF graphics. A study with larger number of patients with monoleaflet valves can be planned to establish rules for these types of valves.

7. Ozkan M, Kaymaz C, Kirma C, et al. Intravenous thrombolytic treatment of mechanical prosthetic valve thrombosis: a study using serial transesophageal echocardiography. J Am Coll Cardiol. 2000;35:1881-9.

8. Koca V, Bozat T, Sarikamis C, et al. The use of transesophageal echocardiography guidance of thrombolytic therapy in prosthetic mitral valve thrombosis. J Heart Valv Dis. 2000;9:374-8.

9. Montorsi $\mathrm{P}$, Cavoretto $\mathrm{D}$, Alimento $\mathrm{M}$, et al. Prosthetic mitral valve thrombosis: can fluoroscopy predict the efficacy of thrombolytic treatment? Circulation 2003; 108 [suppl 1]:1179-84.

10. Muratori M, Montorsi P, Teruzzi G, et al. Feasibility and diagnostic accuracy of quantitative assessment of mechanical prostheses leaflet motion by transthoracic and transesophageal echocardiography in suspected prosthetic valve dysfunction. Am J Cardiol. 2006;97 (1):94-100.

11. Cianciulli TE, Lax JA, Beck MA, et al. Cinefluoroscopic assessment of mechanical disc prostheses: its value as a complementary method to echocardiography. J Heart Valve Dis. 2005; 14 (5):664-73 